Jurnal Health Sains: p-ISSN: 2723-4339 e-ISSN: 2548-1398

Vol. 2, No. 4, April 2021

\title{
HUBUNGAN ANTARA MEROKOK DENGAN DIABETES MELLITUS BERDASARKAN INDEKS MASSA TUBUH (ANALISIS DATA IFLS 5)
}

\section{Dian Kartika Irnayanti dan Krisnawati Bantas}

Universitas Indonesia, Depok, Jawa Barat, Indonesia

Email: dekai.kartika@gmail.com dan krisnabantas@yahoo.com

\begin{tabular}{l}
\hline ARTIKEL INFO \\
\hline Tanggal diterima: 5 April 2021 \\
Tanggal revisi: 15 April 2021 \\
Tanggal yang diterima: 25 \\
April 2021 \\
\hline
\end{tabular}

Keywords:

patient identification; therapy;

transfusion;

specimens; ; patient safety

\begin{abstract}
This study aims to see if there is a difference in smoking risk against diabetes mellitus based on body mass index in the population $\geq 15$ years old in Indonesia. The study design uses cross-sectional with secondary data of Indonesian Household Life Axspects Survey year 2014 or the Indonesia Family Life Survey Wave 5 (IFLS5) conducted by RAND and Survey Meter in 13 provinces in 2014-2015, with a total sampling of 6,302 respondents. The variables studied were diabetes mellitus as a dependent variable and the status of smoking was stratified based on body mass index as an independent variable. Meanwhile, the covariate variable consists of age, gender, marital status, hypertension status, number of cigarettes smoked per day, and length of smoking. Analysis using logistic regression with 95\% CI. The prevalence of diabetes mellitus (undiagnozed diabetes mellitus/UDDM) in this study was 6.6\%. Meanwhile, the prevalence of smoking was $5.2 \%$ of former smokers and $29.6 \%$ of active smokers. In respondents with a thin BMI, dm risk in active smokers $(O R=2.22 ; 95 \%$ CI 0.45-10.97) was different from dm risk in former smokers $(O R=0.50 ; 95 \%$ CI 0.04-6.00), but both showed no significant association. Meanwhile, in obese respondents, dm risk among former smokers $(O R=2.04 ; 95 \%$ CI 0.95-4.37) with active smokers $(O R=1.94 ; 95 \%$ CI 1.01-3.72) is almost the same, where the two show a positive relationship. Meanwhile, in respondents with a normal BMI and an overweight BMI, the risk of DM in active smokers and former smokers was no different from non-smokers. When stratified based on BMI, the risk of DM in active smokers and former smokers looks different. However, these results may be influenced by a lack of information on other potential confounding, especially in variables known to be related to diabetes mellitus, such as central fat.
\end{abstract}

\section{ABSTRAK}

Penelitian ini bertujuan untuk melihat apakah ada perbedaan risiko merokok terhadap diabetes mellitus berdasarkan indeks massa tubuh pada penduduk $\geq 15$ tahun di Indonesia. 


\begin{tabular}{ll}
\hline & Desain studi menggunakan cross-sectional dengan data \\
& sekunder Survei Aspek Kehidupan Rumah Tangga Indonesia \\
& Tahun 2014 atau the Indonesia Family Life Survey Wave 5 \\
& (IFLS5) yang dilaksanakan oleh RAND dan Survey Meter di \\
& 13 provinsi pada tahun 2014-2015, dengan total sampling \\
& sebesar 6.302 responden. Variabel yang diteliti adalah \\
& diabetes mellitus sebagai variabel dependen dan status \\
& merokok yang distratifikasi berdasarkan indeks massa tubuh \\
& sebagai variabel independen. Sementara itu, variabel \\
& kovariat terdiri dari umur, jenis kelamin, status pernikahan, \\
& status hipertensi, jumlah batang rokok yang dihisap perhari, \\
& dan lama merokok. Analisis menggunakan regresi logistik \\
& dengan 95\% CI. Prevalensi diabetes mellitus (undiagnozed \\
& diabetes mellitus/UDDM) dalam penelitian ini adalah \\
& sebesar 6,6\%. Sementara itu, prevalensi merokok adalah \\
& 5,2\% mantan perokok dan 29,6\% perokok aktif. Pada \\
& responden dengan IMT kurus, risiko DM pada perokok aktif \\
& (OR $=2,22 ; 95 \%$ CI 0,45-10,97) berbeda dengan risiko DM \\
pada mantan perokok (OR =0,50; 95\% CI 0,04-6,00), tetapi \\
keduanya tidak menunjukkan hubungan yang signifikan. \\
Sementara itu, pada responden yang obesitas, risiko DM \\
antara mantan perokok (OR = 2,04; 95\% CI 0,95-4,37) \\
dengan perokok aktif (OR = 1,94; 95\% CI 1,01-3,72) hampir \\
sama, dimana keduanya menunjukkan hubungan yang \\
positif. Sementara itu, pada responden dengan IMT normal \\
dan IMT kegemukan, risiko DM pada perokok aktif dan \\
mantan perokok tidak berbeda dengan bukan perokok. \\
Ketika distratifikasi berdasarkan IMT, risiko DM pada \\
perokok aktif dan mantan perokok terlihat berbeda. Namun, \\
hasil ini mungkin dipengaruhi dengan kurangnya informasi \\
terhadap potential confounding lainnya, terutama pada \\
variabel yang diketahui berkaitan dengan diabetes mellitus, \\
seperti lemak sentral. \\
merokok; indeks massa tubuh.
\end{tabular}

\section{Pendahuluan}

Diabetes mellitus sebagai salah satu Penyakit Tidak Menular (PTM) kronis menjadi beban kesehatan di Indonesia. Menurut data Riskesdas, prevalensi diabetes mellitus pada penduduk $\geq 15$ tahun di Indonesia cenderung meningkat, dengan prevalensi sebesar $8,5 \%$ pada tahun 2018 (Isfandari et al., 2019). Indonesia menempati peringkat tujuh di dunia dengan 10,7 juta penderita diabetes mellitus pada tahun 2019 dan diperkirakan menjadi 13,7 juta penderita pada tahun 2030 dan 16,6 juta penderita pada tahun 2045 (Saeedi et al., 2019).

Merokok dan obesitas menjadi salah satu ancaman dan beban kesehatan lainnya 460 yang berkaitan dengan PTM kronis, salah satunya adalah diabetes mellitus. Di Indonesia, prevalensi merokok pada penduduk $\geq 15$ tahun masih menunjukkan trend yang naik-turun, dengan prevalensi sebesar $28,9 \%$ pada tahun 2018 (Isfandari et al., 2019). Berdasarkan

(Wipfli, 2012), diperkirakan sebanyak 64 juta penduduk Indonesia akan tetap mengonsumsi rokok setiap harinya. Sementara itu, prevalensi obesitas umum (berdasarkan indeks massa tubuh) pada penduduk dewasa juga mengalami peningkatan, yaitu 21,8\% pada tahun 2018 (Isfandari et al., 2019).

Merokok dan obesitas masing-masing berhubungan secara positif dengan risiko diabetes. Pada studi meta analisis, diketahui Jurnal Health Sains, Vol 2, No 4, April 2021 
bahwa merokok berisiko 1,38 kali $(95 \%$ CI $1,28-1,49)$ untuk perokok aktif dan 1,19 kali (95\% CI 1,09-1,31) untuk mantan perokok terhadap diabetes mellitus dibandingkan dengan bukan perokok (Akter et al., 2017). Sementara itu memiliki IMT $\geq 25 \mathrm{~kg} / \mathrm{m} 2$ berisiko terhadap diabetes mellitus sebesar 1,55 kali (95\% CI 1,43-1,69) (Kodama et al., 2012). Bahkan ada peningkatan OR $24 \%-44 \%$ per satuan unit perubahan IMT, baik pada perempuan maupun laki-laki (Mehta et al., 2019).

Sementara itu, hubungan antara merokok dan obesitas cenderung berkebalikan (Dare et al., 2015). Perokok cenderung memiliki berat badan yang lebih rendah dibandingkan bukan perokok (Carreras-torres et al., 2019). Namun, berhenti merokok akan memberikan efek negatif terhadap berat badan, dimana mantan perokok cenderung akan bertambah berat badannya ketika berhenti merokok (Campagna et al., 2019). Pada penelitian lain, obesitas memberi efek sinergis terhadap peningkatan risiko DM pada perokok tetapi hasilnya menunjukkan bahwa interaksi antara merokok dengan obesitas terhadap risiko DM tersebut tidak signifikan (Luo et al., 2015).

Oleh karena itu, penelitian ini bertujuan untuk menilai risiko merokok terhadap diabetes mellitus berdasarkan indeks massa tubuh pada penduduk $\geq 15$ tahun di Indonesia.

\section{Metode Penelitian}

\section{Populasi dan Sampel}

Desain penelitian ini adalah crosssectional dengan menggunakan data sekunder Survei Aspek Kehidupan Rumah Tangga Indonesia Tahun 2014 atau the Indonesia Family Life Survey Wave 5 (IFLS5) yang dilaksanakan oleh RAND dan Survey Meter di 13 provinsi pada tahun 2014-2015. Populasi sumber penelitian ini adalah anggota rumah tangga berumur $\geq 15$ tahun yang menjadi responden IFLS5 dan diambil sampel darah kering (dried blood spot/DBS), yaitu 7.014 responden dari 48.139 total responden. Sementara, populasi studinya adalah responden IFLS 5 berumur $\geq 15$ tahun dan diambil sampel darah kering (dried blood spot/DBS), yang telah memenuhi kriteria inklusi dan eksklusi. Kriteria inklusinya adalah memiliki hasil pemeriksaan HbA1c DBS dan whole blood; memiliki data terkait status merokok lengkap, sedangkan kriteria eksklusinya adalah berumur $<15$ tahun $(\mathrm{n}=706)$; tidak memiliki hasil pemeriksaan HbA1c ( $n=285)$; memiliki riwayat DM atau pernah didiagnosis DM oleh dokter $(\mathrm{n}=175)$; hamil $(\mathrm{n}=98)$; serta data tidak lengkap $(n=62)$. Sampel yang digunakan adalah total sampling yang eligible $(n=6.302)$.

\section{Outcome}

Outcome penelitian ini adalah diabetes mellitus berdasarkan hasil pemeriksaan HbAlc. Responden dikategorikan diabetes mellitus jika hasil pemeriksaan $\mathrm{HbA} 1 \mathrm{c} \geq 6,5 \%$. Sampel darah yang diperiksa didapatkan dari sampel darah kering (dried blood spot/DBS), yang diambil melalui pembuluh kapiler pada ujung jari. Sampel darah tersebut lebih mudah dilakukan dibandingkan pembuluh intravena dan lebih dapat bertahan lama dalam hal penyimpanan (Mastronadi et al., 2015). Namun, hasil pemeriksaan HbA1c dari DBS tersebut akan dikonversi terlebih dahulu menjadi HbA1c whole blood, yang merupakan gold standard dari pemeriksaan HbA1c, sehingga dapat digunakan dalam menentukan diagnosis diabetes mellitus dengan menggunakan persamaan sebagai berikut:

HbA1C whole blood equivalent $=$ $1,44 *$ recalculated HbA1c DBS value 0,62 


\section{Pajanan}

Merokok, sebagai pajanan utama, didefinisikan sebagai menghisap rokok (kretek, putih, atau yang dilinting sendiri) yang dilakukan sehari-hari (setiap hari ataupun kadang-kadang) pada masa lalu ataupun masa sekarang. Status merokok dikategorikan menjadi 3, yaitu (1) responden yang tidak pernah sama sekali merokok dianggap bukan perokok; (2) responden yang memiliki kebiasaan merokok tetapi sudah berhenti sama sekali saat penelitian berlangsung dianggap sebagai mantan perokok; dan (3) responden yang masih merokok sampai saat penelitian berlangsung dikategorikan sebagai perokok aktif. Instrumen yang digunakan berupa kuesioner (Buku 3B) dengan wawancara tatap muka oleh pewawancara terlatih.

\section{Kovariat}

Karakteristik responden berupa umur, jenis kelamin, dan status pernikahan didapatkan dari hasil kuesioner 3B. Umur responden dihitung sejak lahir hingga penelitian berlangsung, dikategorikan menjadi <25 tahun, 25-34 tahun, 35-44 tahun, 35-54 tahun, 55-64 tahun, dan $\geq 65$ tahun. Jenis kelamin responden terdiri dari laki-laki dan perempuan. Status pernikahan dikategorikan menjadi dua, yaitu belum menikah dan menikah.

Indeks massa tubuh (IMT) dihitung berdasarkan berat badan (kilogram) dibagi dengan kuadarat tinggi badan (meter) yang diukur sesuai manual pengukuran kesehatan. IMT menggunakan kategori WHO untuk regional Asia Pasifik dengan nilai yang lebih kecil, dengan kategori sebagai berikut: kurus $(<18,5 \mathrm{~kg} / \mathrm{m} 2)$, normal (18,5-22,9 kg/m2), kegemukan (23$24,9 \mathrm{~kg} / \mathrm{m} 2$ ), dan obesitas ( $\geq 25 \mathrm{~kg} / \mathrm{m} 2$ ). Status hipertensi responden ditentukan jika memenuhi salah satu kriteria sebagai berikut, yaitu (1) hasil pengukuran rata-rata tekanan darah sistolik dan diastolik dikategorikan hipertensi jika sistolik $\geq 140$
$\mathrm{mmHg}$ dan/atau diastolik $\geq 90 \mathrm{mmHg}$; dan/atau (2) memiliki riwayat hipertensi atau pernah didiagnosis hipertensi oleh tenaga medis, berdasarkan jawaban kuesioner 3B.

Sementara itu, jumlah batang rokok yang dihisap dihitung berdasarkan jumlah batang rokok rata-rata dalam sehari yang dihabiskan hingga saat wawancara berlangsung atau sebelum berhenti sama sekali, dengan kategori tidak pernah merokok; < 20 batang/hari; dan $\geq 20$ batang/hari. Lama waktu merokok dilihat berdasarkan lama waktu responden sebagai perokok yang dihitung dengan selisih umur antara pertama kali merokok reguler hingga saat penelitian berlangsung (bagi perokok aktif) ataupun hingga berhenti merokok sama sekali (bagi mantan perokok). Kategori yang digunakan adalah tidak pernah merokok; < 10 tahun; dan $\geq 10$ tahun.

\section{Analisis Data}

Analisis deskriptif dilakukan untuk melihat distribusi frekuensi variabel independen (exposure) dan variabel kovariat lainnya. Analisis bivariat dan multivariat menggunakan regresi logistik untuk mendapatkan nilai prevalence odds ratio (POR) dengan 95\% confidence interval. Analisis bivariat dilakukan untuk melihat hubungan antara masing-masing variabel independen dengan kejadian DM. Sementara itu, analisis multivariat dilakukan untuk melihat hubungan status merokok dan diabetes mellitus berdasarkan IMT, setelah dikontrol dengan umur, jenis kelamin, status pernikahan, hipertensi, jumlah batang rokok yang dihisap, dan lama merokok. Analisis multivariat mencakup uji interaksi dan uji confounding. Pengolahan data dilakukan menggunakan SPSS 24

\section{Kaji Etik}

Jurnal Health Sains, Vol 2, No 4, April 2021 
Hubungan Antara Merokok Dengan Diabetes Mellitus Berdasarkan Indeks Massa Tubuh (Analisis Data Ifls 5

IFLS 5, sebagaimana penelitian IFLS sebelumnya, yang menggunakan subjek manusia telah mendapatkan review dan persetujuan dari RAND's Human Subjects Protection Committee (RAND's IRB). Nomor Persetujuan terhadap Protokol Kaji Etik tersebut adalah s006406-01-CR01.

\section{Hasil dan Pembahasan}

A. Hasil Penelitian

\section{Analisis Univariat}

Dalam penelitian ini, prevalensi diabetes mellitus adalah 6,6\%, yaitu 608 responden dari total 6.302 responden. Karakteristik responden dalam penelitian ini adalah sebagai berikut.

\section{Tabel 1}

Distribusi Nilai Variabel Independen pada

\section{Penduduk $\geq 15$ tahun}

\begin{tabular}{|c|c|c|c|c|c|c|}
\hline Variabel & Mean & Median & Modus & $\underline{\text { SD }}$ & Min & $\underline{\text { Max }}$ \\
\hline HbA1c (\%) & 5,54 & 5,44 & 3,5 & $\overline{0,93}$ & 3,5 & 15,7 \\
\hline $\begin{array}{l}\text { Jumlah rokok } \\
\text { (batang/hari) }\end{array}$ & 11 & 12 & 12 & 7,93 & 1 & 66 \\
\hline $\begin{array}{l}\text { Lama meroko } \\
\text { (tahun) }\end{array}$ & 22 & 18 & 5 & 16,53 & 1 & 82 \\
\hline$\overline{\text { Umur (tahun) }}$ & 42 & 39 & 31 & 18,04 & 15 & 95 \\
\hline $\begin{array}{l}\text { Tekanan dara } \\
\text { sistolik (mmH }\end{array}$ & 131 & 125 & 114 & 23,21 & 84 & 245 \\
\hline $\begin{array}{l}\text { Tekanan dara } \\
\text { diastolik (mH }\end{array}$ & 79 & 78 & 76 & 11,77 & 39 & 150 \\
\hline $\begin{array}{l}\text { Indeks Massa } \\
\text { Tubuh }\left(\mathrm{kg} / \mathrm{m}^{2}\right.\end{array}$ & 22,94 & 22,30 & 18,50 & 4,45 & 12,00 & 51,38 \\
\hline
\end{tabular}

Berdasarkan tabel 1 diketahui bahwa rata-rata kadar $\mathrm{HbA} 1 \mathrm{c}$ responden adalah $5,54 \%$, degan nilai paling banyak adalah 3,5\%. Responden mengonsumsi rokok rata-rata 11 batang/hari dan merokok selama hidupnya rata-rata 22 tahun. Umur rata-rata responden adalah 42 tahun. Rata-rata tekanan darah sistolik responden berada di atas normal, yaitu $131 \mathrm{mmHg}$, sedangkan tekanan darah diastolik rata-rata masih tergolong normal, yaitu $79 \mathrm{mmHg}$. Sementara itu rata-rata IMT responden tergolong normal, yaitu $22,9 \mathrm{~kg} / \mathrm{m} 2$.
Tabel 2

Distribusi Frekuensi Karakteristik

\section{Responden Berdasarkan Status Merokok} pada Penduduk $\geq 15$ tahun

\begin{tabular}{|c|c|c|}
\hline \multirow{2}{*}{$\begin{array}{r}\text { Kategori } \\
\text { Status merokok } \\
\end{array}$} & \multicolumn{2}{|c|}{$\mathbf{N}(\%)$} \\
\hline & & \\
\hline Perokok aktif & 1868 & $(29,6)$ \\
\hline Mantan perokok & 328 & $(5,2)$ \\
\hline Bukan perokok & 4106 & $(65,2)$ \\
\hline \multicolumn{3}{|l|}{$\begin{array}{l}\text { Banyaknya batang } \\
\text { rokok }\end{array}$} \\
\hline$\geq 20$ batang/hari & 268 & $(4,3)$ \\
\hline$<20$ batang/hari & 1928 & $(30,6)$ \\
\hline Tidak merokok & 4106 & $(65,2)$ \\
\hline \multicolumn{3}{|l|}{ Lama merokok } \\
\hline$\geq 10$ tahun & 1593 & $(25,3)$ \\
\hline$<10$ tahun & 603 & $(9,6)$ \\
\hline Tidak merokok & 4106 & $(65,2)$ \\
\hline \multicolumn{3}{|l|}{ Umur } \\
\hline$<25$ tahun & 1207 & $(19,2)$ \\
\hline 25-34 tahun & 1426 & $(22,6)$ \\
\hline 35-44 tahun & 1074 & $(17,0)$ \\
\hline 45-54 tahun & 725 & $(11,5)$ \\
\hline 55-64 tahun & 1024 & $(16,2)$ \\
\hline$\geq 65$ tahun & 846 & $(13,4)$ \\
\hline \multicolumn{3}{|l|}{ Jenis kelamin } \\
\hline Laki-laki & 2840 & $(45,1)$ \\
\hline Perempuan & 3462 & $(54,9)$ \\
\hline \multicolumn{3}{|l|}{ Status pernikahan } \\
\hline Menikah & 4990 & $(79,2)$ \\
\hline Belum menikah & 1312 & $(20,8)$ \\
\hline \multicolumn{3}{|l|}{ Hipertensi } \\
\hline $\mathrm{Ya}$ & 1873 & $(29,7)$ \\
\hline Tidak & 4429 & $(70,3)$ \\
\hline \multicolumn{3}{|l|}{$\begin{array}{l}\text { Indeks massa tubuh } \\
\text { (IMT) }\end{array}$} \\
\hline Obesitas & 1860 & $(29,5)$ \\
\hline Kegemukan & 1168 & $(18,5)$ \\
\hline Normal & 2347 & $(37,2)$ \\
\hline Kurus & 927 & $(14,7)$ \\
\hline
\end{tabular}

Berdasarkan status merokok, $65,2 \%$ responden bukan perokok, 5,2\% mantan perokok, dan $29,6 \%$ perokok aktif. Distribusi umur terbanyak cenderung pada kelompok muda, yaitu 25-34 tahun $(22,6 \%)$ dan $<25$ tahun $(19,2 \%)$. Responden lebih banyak yang menikah $(79,2 \%)$, perempuan $(54,9 \%)$, dan tidak hipertensi (70,3\%). Responden paling banyak tergolong normal $(37,2 \%)$ responden dan diikuti oleh obesitas $(29,5 \%)$. 
2. Analisis Bivariat

Tabel 3

Hubungan antara Karakteristik

Responden dan Status Merokok dengan Diabetes Mellitus pada Penduduk $\geq 15$ tahun

\begin{tabular}{|c|c|c|c|c|c|c|c|}
\hline \multirow[t]{2}{*}{ Kategori } & \multicolumn{2}{|r|}{ DM } & \multicolumn{2}{|c|}{ Tidak DM } & \multicolumn{2}{|c|}{$\begin{array}{l}\text { POR (95\% } \\
\text { CI) }\end{array}$} & \multirow[t]{3}{*}{$p$ value } \\
\hline & $\mathbf{N}$ & $(\%)$ & $\underline{\mathbf{N}}$ & $(\%)$ & & & \\
\hline \multicolumn{7}{|l|}{$\begin{array}{l}\text { Status } \\
\text { merokok }\end{array}$} & \\
\hline $\begin{array}{l}\text { Perokok } \\
\text { aktif }\end{array}$ & 109 & $(26,1)$ & 1759 & $(29,9)$ & 0,86 & $\begin{array}{l}(0,69- \\
1,09)\end{array}$ & $\begin{array}{c}0,20 \\
8\end{array}$ \\
\hline $\begin{array}{l}\text { Mantan } \\
\text { perokok }\end{array}$ & 34 & $(\mathbf{8 , 1})$ & 294 & $(\mathbf{5 , 0 )}$ & 1,61 & $\begin{array}{l}(1,11- \\
2,35)\end{array}$ & $\begin{array}{c}0,01 \\
3\end{array}$ \\
\hline $\begin{array}{l}\text { Bukan } \\
\text { perokok }\end{array}$ & 275 & $(65,8)$ & 3831 & $(65,1)$ & 1 & & \\
\hline \multicolumn{8}{|l|}{$\begin{array}{l}\text { Jumlah batang } \\
\text { rokok yang } \\
\text { dihisap } \\
\end{array}$} \\
\hline $\begin{array}{l}\geq 20 \\
\text { batang/hari }\end{array}$ & 22 & $(5,9)$ & 246 & $(4,2)$ & 1,25 & $\begin{array}{l}(0,79- \\
1,96)\end{array}$ & $\begin{array}{c}0,34 \\
2\end{array}$ \\
\hline $\begin{array}{l}20 \\
\text { batang/hari }\end{array}$ & 121 & $(\mathbf{1 0 , 5 )}$ & 1807 & $(30,7)$ & $\mathbf{0 , 9 3}$ & $\begin{array}{l}(0,75- \\
1,16)\end{array}$ & $\begin{array}{c}0,53 \\
8\end{array}$ \\
\hline $\begin{array}{l}\begin{array}{l}\text { Tidak } \\
\text { merokok }\end{array} \\
\end{array}$ & 275 & $(65,8)$ & 3831 & $(65,1)$ & 1 & & \\
\hline \multicolumn{8}{|l|}{$\begin{array}{l}\text { Lama } \\
\text { merokok }\end{array}$} \\
\hline$\geq 10$ tahun & 120 & $(28,7)$ & 1473 & $(25,0)$ & 1,14 & $\begin{array}{l}(0,91- \\
1,42)\end{array}$ & $\begin{array}{c}0,26 \\
5\end{array}$ \\
\hline$<10$ tahun & 23 & $(5,5)$ & 580 & $(9,9)$ & 0,55 & $\begin{array}{l}(\mathbf{0 , 3 6 -} \\
\mathbf{0 , 8 5})\end{array}$ & $\begin{array}{c}0,00 \\
7\end{array}$ \\
\hline $\begin{array}{l}\text { Tidak } \\
\text { merokok }\end{array}$ & 275 & $(65,8)$ & 3831 & $(65,1)$ & 1 & & \\
\hline \multicolumn{8}{|l|}{ Umur } \\
\hline$\geq 65$ tahun & 86 & $(\mathbf{2 0 , 6 )}$ & 760 & $(12,9)$ & 6,39 & $\begin{array}{l}(3,93- \\
10,39) \\
\end{array}$ & $\begin{array}{c}0,00 \\
\underline{0}\end{array}$ \\
\hline $\begin{array}{l}55-64 \\
\text { tahun } \\
\end{array}$ & 119 & $(28,5)$ & 905 & $(15,4)$ & 7,43 & $\begin{array}{l}(4,63- \\
11,90)\end{array}$ & $\begin{array}{c}0,00 \\
0\end{array}$ \\
\hline $\begin{array}{l}45-54 \\
\text { tahun }\end{array}$ & 63 & $(15,1)$ & 662 & $(11,3)$ & 5,38 & $\begin{array}{l}(3,25- \\
8,89)\end{array}$ & $\begin{array}{c}0,00 \\
0\end{array}$ \\
\hline $\begin{array}{l}35-44 \\
\text { tahun }\end{array}$ & 81 & $(\mathbf{1 9 , 4 )}$ & 993 & $(16,9)$ & 4,61 & $\begin{array}{l}(2,83- \\
7,50)\end{array}$ & $\begin{array}{c}0,00 \\
0\end{array}$ \\
\hline $\begin{array}{l}25-34 \\
\text { tahun } \\
\end{array}$ & 48 & $(11,5)$ & 1378 & $(23,4)$ & 1,97 & $\begin{array}{l}(\mathbf{1 , 1 7 -}- \\
\mathbf{3 , 3 0 )} \\
\end{array}$ & $\begin{array}{c}0,01 \\
1\end{array}$ \\
\hline$<25$ tahun & 21 & $(\mathbf{5 , 0 )}$ & 1186 & $(20,2)$ & 1 & & \\
\hline \multicolumn{8}{|l|}{ Jenis kelamin } \\
\hline Laki-laki & 175 & $(41,9)$ & 2665 & $(45,3)$ & 0,87 & $\begin{array}{l}(0,71- \\
1,06)\end{array}$ & $\begin{array}{c}0,17 \\
4\end{array}$ \\
\hline Perempuan & 243 & $(\mathbf{5 8 , 1 )}$ & 3219 & $(54,7)$ & 1 & & \\
\hline \multicolumn{8}{|l|}{$\begin{array}{l}\text { Status } \\
\text { Pernikahan }\end{array}$} \\
\hline Menikah & 379 & $(90,7)$ & 4611 & $(\mathbf{7 8 , 4 )}$ & 2,68 & $\begin{array}{l}(1,92- \\
3,75)\end{array}$ & $\begin{array}{c}0,00 \\
0\end{array}$ \\
\hline $\begin{array}{l}\text { Belum } \\
\text { menikah }\end{array}$ & 39 & $(\mathbf{9 , 3})$ & 1273 & $(\mathbf{2 1 , 6 )}$ & 1 & & \\
\hline \multicolumn{8}{|l|}{ Hipertensi } \\
\hline Ya & 235 & $(56,2)$ & 1638 & $(27,8)$ & 3,33 & $\begin{array}{l}(2,72- \\
4,07) \\
\end{array}$ & $\begin{array}{c}\mathbf{0 , 0 0} \\
\mathbf{0}\end{array}$ \\
\hline Tidak & 183 & $(43,8)$ & 4246 & $(72,2)$ & 1 & & \\
\hline \multicolumn{8}{|l|}{$\begin{array}{l}\text { Indeks massa } \\
\text { tubuh }\end{array}$} \\
\hline Obesitas & 233 & $(55,7)$ & 1627 & $(27,7)$ & 3,63 & $\begin{array}{l}(2,82- \\
4,68)\end{array}$ & $\begin{array}{c}0,00 \\
0\end{array}$ \\
\hline Kegemukan & 66 & $(15,8)$ & 1102 & $(\mathbf{1 8 , 7 )}$ & 1,52 & $\begin{array}{l}(1,10- \\
2,11)\end{array}$ & $\begin{array}{c}0,01 \\
2\end{array}$ \\
\hline Kurus & 30 & $(7,2)$ & 897 & $(15,2)$ & $\mathbf{0 , 8 5}$ & $\begin{array}{l}(0,56- \\
1,30)\end{array}$ & $\begin{array}{c}0,44 \\
4 \\
\end{array}$ \\
\hline Normal & 89 & $(21,3)$ & 2258 & $(38,4)$ & 1 & & \\
\hline
\end{tabular}

Berdasarkan status merokok, mantan perokok berisiko 1,61 kali (95\% 1,11-2,35) terhadap DM sementara perokok aktif justru berisiko 16,4\% (OR $=0,86,95 \% \mathrm{CI}(0,69-1,09)$ lebih rendah terhadap DM, dibandingkan dengan bukan perokok. Jumlah batang rokok yang dihisap tidak menunjukkan adanya hubungan yang signifikan dengan DM. Dibandingkan tidak merokok, lama merokok $\geq 10$ tahun hanya berisiko $14 \%$ lebih tinggi $(\mathrm{OR}=1,14,95 \% \mathrm{CI} 0,91$ $1,42)$ sementara merokok $<10$ tahun justru berisiko $45 \%(\mathrm{OR}=0,55,95 \% \mathrm{CI}$ 0,36-0,85) lebih rendah untuk mengalami DM.

Proporsi responden yang mengalami DM meningkat berdasarkan kelompok umur. Risiko DM juga diketahui cenderung meningkat dengan bertambahnya umur, yaitu 1,97 (95\% CI 1,17-3,30); 4,61 (95\% CI 2,83-7,50); 5,38 (95\% CI 3,25-8,89); 7,43 (95\% CI 4,63-11,90); dan 6,39 (95\% CI 3,93$10,39)$ berturut-turut untuk kelompok umur, dibandingkan dengan kelompok umur yang paling muda ( $<25$ tahun). Proporsi laki-laki dan perempuan hampir sama dan tidak ada hubungan yang signifikan anatar jenis kelamin dengan risiko terhadap DM ( $\mathrm{p}=0,174)$. Responden yang menikah berisiko 3,68 kali $(95 \%$ CI 1,92-3,75) mengalami DM dibandingkan yang belum menikah. Lebih dari setengah $(56,2 \%)$ orang yang DM mengalami hipertensi, dan risiko mengalami DM pada orang hipertensi 3,33 kali (95\% CI 2,72-4,07) dibandingkan yang tidak hipertensi. Risiko mengalami DM juga meningkat berdasarkan kategori IMT, yaitu 1,52 kali $(95 \%$ CI 1,10-2,11) untuk responden dengan kegemukan dan 3,63 kali $\quad(95 \%$ CI 2,82-4,68) untuk responden dengan obesitas dibandingkan responden dengan IMT normal. Sementara, risiko responden kurus untuk mengalami DM justru 15\% $(\mathrm{OR}=0,85,95 \%$ CI 0,56-1,30) lebih rendah dibandingkan responden dengan IMT normal. 
Hubungan Antara Merokok Dengan Diabetes Mellitus Berdasarkan Indeks Massa Tubuh

(Analisis Data Ifls 5

Tabel 4

Hubungan Status Merokok dengan Diabetes Mellitus Berdasarkan IMT pada Penduduk $\geq 15$ tahun

\begin{tabular}{|c|c|c|c|c|c|c|}
\hline \multirow[t]{2}{*}{$\begin{array}{c}\text { Kategori } \\
\text { IMT }\end{array}$} & \multirow[t]{2}{*}{$\begin{array}{c}\text { Status } \\
\text { Merokok }\end{array}$} & DM & \multirow{2}{*}{$\begin{array}{c}\text { Tidak } \\
\text { DM } \\
\mathbf{N}(\%)\end{array}$} & \multirow[t]{2}{*}{ POI } & \multirow[t]{2}{*}{$\begin{array}{l}95 \% \\
\text { CI) }\end{array}$} & \multirow[t]{2}{*}{$\begin{array}{c}p \\
\text { valu } \\
\underline{e} \\
\end{array}$} \\
\hline & & $\mathbf{N} \quad(\%)$ & & & & \\
\hline \multirow[t]{3}{*}{ Obesitas } & $\begin{array}{l}\text { Perokok } \\
\text { aktif }\end{array}$ & $49(21,0)$ & $276(17,0)$ & 1,36 & $0,97-1,9$ & 20,078 \\
\hline & $\begin{array}{l}\text { Mantan } \\
\text { perokok }\end{array}$ & $17 \quad(7,3)$ & $69(4,2)$ & $\mathbf{1 , 8 9}$ & $\begin{array}{l}(1,09- \\
3,30)\end{array}$ & 0,024 \\
\hline & $\begin{array}{l}\text { Bukan } \\
\text { perokok }\end{array}$ & $\begin{array}{c}16(71,7) \\
7\end{array}$ & $1282(78,8)$ & 1 & & \\
\hline \multirow[t]{3}{*}{$\begin{array}{l}\text { Kegemu } \\
\text { kan }\end{array}$} & $\begin{array}{l}\text { Perokok } \\
\text { aktif } \\
\end{array}$ & $1624,2)$ & $284(25,8)$ & 0,95 & $\begin{array}{l}(0,53- \\
1,72) \\
\end{array}$ & $\overline{0,872}$ \\
\hline & $\begin{array}{l}\text { Mantan } \\
\text { perokok }\end{array}$ & $\begin{array}{ll}6 & (9,1)\end{array}$ & $74(6,7)$ & 1,37 & $\begin{array}{l}(\mathbf{0 , 5 7 -} \\
\mathbf{3 , 3 3 )} \\
\end{array}$ & $\overline{0,485}$ \\
\hline & $\begin{array}{l}\text { Bukan } \\
\text { perokok }\end{array}$ & $44(67,5)$ & $744(67,5)$ & 1 & & \\
\hline \multirow[t]{3}{*}{ Normal } & $\begin{array}{l}\text { Perokok } \\
\text { aktif }\end{array}$ & $26(29,2)$ & $885(39,2)$ & 0,71 & $\begin{array}{l}(\mathbf{0 , 4 4 -} \\
\mathbf{1 , 1 4 )}\end{array}$ & 0,157 \\
\hline & $\begin{array}{l}\text { Mantan } \\
\text { perokok }\end{array}$ & $10(11,2)$ & $95(4,2)$ & 2,54 & $\begin{array}{l}(1,25- \\
5,15)\end{array}$ & $\mathbf{0 , 0 1 0}$ \\
\hline & $\begin{array}{l}\text { Bukan } \\
\text { perokok }\end{array}$ & $53(59,6)$ & $1278(56,6)$ & 1 & & \\
\hline \multirow[t]{3}{*}{ Kurus } & $\begin{array}{l}\text { Perokok } \\
\text { aktif }\end{array}$ & $18(60,0)$ & $314(35,0)$ & 2,75 & $\begin{array}{l}(1,28- \\
5,89) \\
\end{array}$ & 0,009 \\
\hline & $\begin{array}{l}\text { Mantan } \\
\text { perokok }\end{array}$ & $1 \quad(3,3)$ & $\begin{array}{ll}56 & (6,2)\end{array}$ & 0,86 & $\begin{array}{l}(0,11- \\
6,75) \\
\end{array}$ & 0,882 \\
\hline & $\begin{array}{l}\text { Bukan } \\
\text { perokok }\end{array}$ & $11(36,7)$ & $527(58,8)$ & 1 & & \\
\hline
\end{tabular}

Tabel 4 menunjukkan bahwa ada perbedaan risiko DM berdasarkan kategori IMT pada perokok aktif dan mantan perokok dibandingkan pada bukan perokok. Pada responden yang obesitas, mantan perokok berisiko 1,89 kali (95\% CI 1,09-3,30) sedangkan perokok aktif hanya berisiko 1,36 kali (95\% CI 0,97-1,92) terhadap DM, jika dibandingkn dengan bukan perokok. Pada responden yang kegemukan, tidak menunjukkan adanya hubungan yang signifikan antara merokok dengan DM, baik pada perokok aktif maupun mantan perokok. Pada responden dengan IMT normal, mantan perokok (OR $=2,54$, 95\% CI 1,25-5,15) justru memiliki risiko DM yang lebih kuat sementara perokok aktif menunjukkan asosiasi negatif tetapi hasilnya tidak signifikan $(\mathrm{p}=0,157)$. Sementara itu, pada responden kurus, perokok aktif berisiko 2,75 kali (95\% CI 1,28-5,89) mengalami DM dibandingkan bukan perokok, sedangkan mantan perokok tidak menunjukkan hubungan yang signifikan $(\mathrm{p}=0,882)$.

3. Analisis Multivariat

Berdasarkan analisis multivariat awal, didapatkan hasil bahwa umur dan hipertensi menunjukkan hasil yang signifikan pada model multivariat. Uji interaksi dilakukan terhadap dua variabel tersebut tetapi hasilnya menunjukkan tidak adanya interaksi. Selanjutnya dilakukan uji confounding dan hasilnya menunjukkan bahwa umur dan hipertensi saja yang merupakan variabel confounding dengan perubahan POR $\geq 10 \%$ dalam penelitian ini. Hasil akhir multivariat ditunjukkan dalam tabel berikut.

Tabel 5

Analisis Multivariat Hubungan antara Status Merokok dengan Diabetes Mellitus pada Penduduk $\geq 15$ tahun dengan IMT

Kurus

\begin{tabular}{|c|c|c|c|c|c|}
\hline Variabel & Kategori & $\beta$ & $\begin{array}{c}\mathbf{p} \\
\text { value }\end{array}$ & POR & $\begin{array}{l}(\mathbf{9 5 \%} \% \\
\text { CI) }\end{array}$ \\
\hline \multirow[t]{3}{*}{$\begin{array}{l}\text { Status } \\
\text { merokok }\end{array}$} & $\begin{array}{l}\text { Perokok } \\
\text { aktif }\end{array}$ & 0,797 & 0,328 & 2,22 & $\begin{array}{l}(0,45- \\
10,97) \\
\end{array}$ \\
\hline & $\begin{array}{l}\text { Mantan } \\
\text { perokok }\end{array}$ & $-0,695$ & 0,584 & 0,50 & $\begin{array}{l}(\mathbf{0 , 0 4 -} \\
\mathbf{6 , 0 0 )}\end{array}$ \\
\hline & $\begin{array}{l}\text { Bukan } \\
\text { perokok }\end{array}$ & & & 1 & \\
\hline \multirow{2}{*}{$\begin{array}{l}\text { Jumlah } \\
\text { rokok yang } \\
\text { dihisap }\end{array}$} & $\begin{array}{l}\mathbf{2 0} \\
\text { batang/hari }\end{array}$ & $-0,075$ & 0,924 & $\overline{0,93}$ & $\begin{array}{l}(0,20- \\
4,30)\end{array}$ \\
\hline & $\begin{array}{l}<20 \\
\text { batang/hari }\end{array}$ & & & 1 & \\
\hline \multirow[t]{2}{*}{$\begin{array}{l}\text { Lama } \\
\text { merokok }\end{array}$} & & 0,943 & 0,178 & 2,57 & $\begin{array}{l}(0,65- \\
10,14) \\
\end{array}$ \\
\hline & $<10$ tahun & & & 1 & \\
\hline \multirow[t]{6}{*}{ Umur } & $\geq 65$ tahun & 1,507 & 0,050 & 4,52 & $\begin{array}{l}1,00- \\
20,36) \\
\end{array}$ \\
\hline & 55-64 tahun & 2,112 & 0,003 & 8,26 & $\begin{array}{l}(2,023- \\
33,72)\end{array}$ \\
\hline & 45-54 tahun & $-16,599$ & 0,997 & - & \\
\hline & 35-44 tahun & 1,243 & 0,154 & 3,47 & $\begin{array}{l}(0,63- \\
19,14) \\
\end{array}$ \\
\hline & & 0,500 & 0,472 & 1,65 & $\begin{array}{l}(0,42- \\
6,45) \\
\end{array}$ \\
\hline & $<25$ tahun & & & & \\
\hline \multirow[t]{2}{*}{ Hipertensi } & Ya & $-0,109$ & 0,823 & 0,90 & $\begin{array}{l}(0,35- \\
2,33)\end{array}$ \\
\hline & Tidak & & & & \\
\hline
\end{tabular}

Berdasarkan tabel 5, pada responden dengan IMT kurus, mantan perokok berisiko 0,50 kali $95 \%$ CI $(0,04-6,00) \quad$ mengalami DM 
dibandingkan bukan perokok, setelah dikontrol dengan jumlah rokok yang dihisap, lama merokok, umur, dan hipertensi. Sebaliknya, perokok aktif dengan IMT kurus berisiko 2,22 kali (95\% CI 0,45-10,97) mengalami DM dibandingkan dengan bukan perokok dengan IMT kurus, setelah dikontrol dengan jumlah rokok yang dihisap, lama merokok, umur, dan hipertensi. Namun, keduanya menunjukkan hasil yang tidak signifikan secara statistik.

\section{Tabel 6}

Analisis Multivariat Hubungan antara Status Merokok dengan Diabetes Mellitus pada Penduduk $\geq 15$ tahun dengan IMT

\begin{tabular}{|c|c|c|c|c|c|}
\hline Variabel & Kategori & $\beta$ & $\begin{array}{c}\mathbf{p} \\
\text { value }\end{array}$ & POR & $\begin{array}{l}\text { (95\% } \\
\text { CI) }\end{array}$ \\
\hline \multirow[t]{3}{*}{$\begin{array}{l}\text { Status } \\
\text { merokok }\end{array}$} & Perokok aktif & $-1,041$ & 0,166 & 0,35 & $\begin{array}{l}(0,08 \\
1,54) \\
\end{array}$ \\
\hline & $\begin{array}{l}\text { Mantan } \\
\text { perokok }\end{array}$ & $-0,144$ & 0,856 & 0,86 & $\begin{array}{l}(0,18 \\
4,11)\end{array}$ \\
\hline & $\begin{array}{l}\text { Bukan } \\
\text { perokok }\end{array}$ & & & 1 & \\
\hline \multirow{2}{*}{$\begin{array}{l}\text { Jumlah } \\
\text { rokok } \\
\text { yang } \\
\text { dihisap }\end{array}$} & $\begin{array}{l}\geq 20 \\
\text { batang/hari }\end{array}$ & 0,796 & 0,284 & 2,22 & $\begin{array}{l}\mathbf{( 0 , 5 2 -} \\
\mathbf{9 , 5 1 )}\end{array}$ \\
\hline & $\begin{array}{l}<20 \\
\text { batang/hari }\end{array}$ & & & 1 & \\
\hline \multirow[t]{2}{*}{$\begin{array}{l}\text { Lama } \\
\text { merokok }\end{array}$} & $\geq 10$ tahun & $-0,268$ & 0,612 & 0,77 & $\begin{array}{l}(\mathbf{0 , 2 7} \\
\mathbf{2 , 1 5}) \\
\end{array}$ \\
\hline & $<10$ tahun & & & 1 & \\
\hline \multirow[t]{6}{*}{ Umur } & $\geq 65$ tahun & 1,410 & 0,001 & 4,10 & $\begin{array}{l}(1,76- \\
9,53) \\
\end{array}$ \\
\hline & 55-64 tahun & 0,648 & 0,154 & 1,91 & $\begin{array}{l}(0,78- \\
4,66) \\
\end{array}$ \\
\hline & 45-54 tahun & 0,421 & 0,421 & 1,52 & $\begin{array}{l}(0,55 \\
4,25) \\
\end{array}$ \\
\hline & 35-44 tahun & 0,462 & 0,340 & 1,59 & $\begin{array}{l}(0,62- \\
4,10) \\
\end{array}$ \\
\hline & 25-34 tahun & 0,341 & 0,436 & 1,41 & $\begin{array}{l}(0,60- \\
3,32) \\
\end{array}$ \\
\hline & $<25$ tahun & & & & \\
\hline \multirow[t]{2}{*}{$\begin{array}{l}\text { Hipert } \\
\text { ensi }\end{array}$} & Ya & 0,724 & 0,005 & 2,06 & $\begin{array}{l}\mathbf{1 , 2 4} \\
\mathbf{3 , 4 4}) \\
\end{array}$ \\
\hline & $\begin{array}{l}\text { Tidak } \\
\end{array}$ & & & 1 & \\
\hline
\end{tabular}

Berdasarkan tabel 6, pada responden dengan IMT normal, risiko mengalami DM pada mantan perokok sebesar 0,86 kali $(95 \%$ CI $0,18-4,11)$ dan pada perokok aktif sebesar 0,35 kali (95\% CI 0,08-1,54) dibandingkan dengan bukan perokok, setelah dikontrol dengan jumlah rokok yang dihisap, lama merokok, umur, dan hipertensi. Namun, kedua hasil tersebut menunjukkan hasil yang tidak signifikan secara statistik.

Tabel 7

Analisis Multivariat Hubungan antara Status Merokok dengan Diabetes Mellitus pada Penduduk $\geq 15$ tahun dengan IMT Kegemukan

\begin{tabular}{|c|c|c|c|c|c|}
\hline Variabel & Kategori & $\beta$ & $\begin{array}{c}\mathbf{p} \\
\text { value }\end{array}$ & POR & $\begin{array}{l}(95 \% \\
\text { CI) }\end{array}$ \\
\hline \multirow[t]{3}{*}{$\begin{array}{l}\text { Status } \\
\text { merokok }\end{array}$} & $\begin{array}{l}\text { Perokok } \\
\text { aktif }\end{array}$ & $-0,034$ & 0,958 & 0,97 & $\begin{array}{l}(\mathbf{0 , 2 7 -} \\
\mathbf{3 , 4 3})\end{array}$ \\
\hline & $\begin{array}{l}\text { Mantan } \\
\text { perokok }\end{array}$ & $-0,071$ & 0,922 & 0,93 & $\begin{array}{l}(0,23- \\
3,82)\end{array}$ \\
\hline & $\begin{array}{l}\text { Bukan } \\
\text { perokok }\end{array}$ & & & 1 & \\
\hline \multirow{2}{*}{$\begin{array}{l}\text { Jumlah } \\
\text { rokok } \\
\text { yang } \\
\text { dihisap }\end{array}$} & $\begin{array}{l}\geq 20 \\
\text { batang/hari }\end{array}$ & $-0,118$ & $\mathbf{0 , 8 5 7}$ & 0,89 & $\begin{array}{l}(0,25- \\
3,22)\end{array}$ \\
\hline & $\begin{array}{l}<20 \\
\text { batang/hari }\end{array}$ & & & 1 & \\
\hline \multirow[t]{2}{*}{$\begin{array}{l}\text { Lama } \\
\text { merokok }\end{array}$} & & 0,394 & 0,517 & 1,48 & $\begin{array}{l}(0,45- \\
4,87)\end{array}$ \\
\hline & $<10$ tahun & & & 1 & \\
\hline \multirow[t]{6}{*}{ Umur } & $\geq 65$ tahun & 1,408 & 0,024 & 4,09 & $\begin{array}{l}(1,20- \\
13,91) \\
\end{array}$ \\
\hline & 55-64 tahun & 1,205 & 0,045 & 3,34 & $\begin{array}{l}(1,03- \\
10,84)\end{array}$ \\
\hline & 45-54 tahun & 1,060 & 0,084 & 2,89 & $\begin{array}{l}(0,87- \\
9,61)\end{array}$ \\
\hline & 35-44 tahun & 0,442 & 0,481 & 1,56 & $\begin{array}{l}(0,45- \\
5,33)\end{array}$ \\
\hline & 25-34 tahun & $-0,270$ & 0,682 & 0,76 & $\begin{array}{l}(\mathbf{0 , 2 1 -} \\
2,77)\end{array}$ \\
\hline & $<25$ tahun & & & & \\
\hline \multirow[t]{2}{*}{ Hipertensi } & Ya & 0,234 & 0,443 & 1,26 & $\begin{array}{l}(0,70- \\
2,30) \\
\end{array}$ \\
\hline & Tidak & & & 1 & \\
\hline
\end{tabular}

Berdasarkan tabel 7, pada responden yang kegemukan, status merokok tidak menunjukkan hubungan yang signifikan, dimana risiko DM, baik pada mantan perokok mapun perokok aktif hampir sama atau mendekati risiko DM pada bukan perokok.

\section{Tabel 8}

Analisis Multivariat Hubungan antara Status Merokok dengan Diabetes Mellitus pada Penduduk $\geq 15$ tahun dengan IMT Obesitas

\begin{tabular}{|c|c|c|c|c|c|}
\hline Variabel & Kategori & $\beta$ & $\begin{array}{c}\mathbf{p} \\
\text { value }\end{array}$ & POR & $\begin{array}{l}\text { (95\% } \\
\text { CI) }\end{array}$ \\
\hline \multirow[t]{4}{*}{$\begin{array}{l}\text { Status } \\
\text { merokok }\end{array}$} & $\begin{array}{l}\text { Perokok } \\
\text { aktif }\end{array}$ & 0,663 & 0,046 & 1,94 & $\begin{array}{l}(1,01- \\
3,72) \\
\end{array}$ \\
\hline & $\begin{array}{l}\text { Mantan } \\
\text { perokok }\end{array}$ & 0,710 & 0,068 & 2,04 & $\begin{array}{l}0,95- \\
4,37) \\
\end{array}$ \\
\hline & $\begin{array}{l}\text { Bukan } \\
\text { perokok }\end{array}$ & & & 1 & \\
\hline & $\begin{array}{l}\geq 20 \\
\text { batang/hari }\end{array}$ & $-0,270$ & 0,432 & 0,76 & $\begin{array}{l}(\mathbf{0 , 3 9 -} \\
1,50)\end{array}$ \\
\hline
\end{tabular}


Hubungan Antara Merokok Dengan Diabetes Mellitus Berdasarkan Indeks Massa Tubuh (Analisis Data Ifls 5

\begin{tabular}{|c|c|c|c|c|c|}
\hline Variabel & Kategori & $\beta$ & $\begin{array}{c}\mathbf{p} \\
\text { value }\end{array}$ & POR & $\begin{array}{l}(\mathbf{9 5} \% \\
\text { CI) }\end{array}$ \\
\hline $\begin{array}{l}\text { Jumlah } \\
\text { rokok yang } \\
\text { dihisap }\end{array}$ & $\begin{array}{l}<20 \\
\text { batang/hari }\end{array}$ & & & 1 & \\
\hline \multirow[t]{2}{*}{$\begin{array}{l}\text { Lama } \\
\text { merokok }\end{array}$} & & $-0,523$ & 0,213 & 0,59 & $\begin{array}{l}(0,26- \\
1,35) \\
\end{array}$ \\
\hline & $<10$ tahun & & & 1 & \\
\hline \multirow[t]{6}{*}{ Umur } & $\geq 65$ tahun & 2,073 & 0,006 & 7,95 & $\begin{array}{l}\left(\mathbf{1 , 8 1 -}-{ }_{35,03)}\right. \\
\text { (3) }\end{array}$ \\
\hline & 55-64 tahun & 2,535 & 0,001 & 12,62 & $\begin{array}{l}(3,01- \\
52,85)\end{array}$ \\
\hline & 45-54 tahun & 2,240 & 0,002 & 9,40 & $\begin{array}{l}(2,22- \\
39,73)\end{array}$ \\
\hline & 35-44 tahun & 2,151 & 0,003 & 8,60 & $\begin{array}{l}(2,06- \\
35,91)\end{array}$ \\
\hline & 25-34 tahun & 1,355 & 0,068 & 3,88 & $\begin{array}{l}(0,91- \\
16,58) \\
\end{array}$ \\
\hline & $<25$ tahun & & & & \\
\hline \multirow[t]{2}{*}{ Hipertensi } & Ya & 0,771 & 0,000 & 2,16 & $\begin{array}{l}(\mathbf{1 , 5 8 -}- \\
2,96)\end{array}$ \\
\hline & Tidak & & & 1 & \\
\hline
\end{tabular}

Berdasarkan tabel 8, risiko mengalami DM pada perokok aktif yang obesitas sebesar 1,94 kali (95\% CI 1,013,72 ) dibandingkan dengan bukan perokok yang obesitas, setelah dikontrol dengan jumlah rokok yang dihisap, lama merokok, umur, dan hipertensi. Sementara itu, risiko mengalami DM pada mantan perokok yang obesitas sebesar 2,04 kali $(95 \%$ CI $0,95-4,37)$ dibandingkan dengan bukan perokok yang obesitas, setelah dikontrol dengan jumlah rokok yang dihisap, lama merokok, umur, dan hipertensi. Hasil antara keduanya menunjukkan risiko yang tidak berbeda jauh tetapi pada mantan tidak menunjukkan hasil yang signifikan secara statistik.

B. Pembahasan

Pada penelitian ini terlihat bahwa perokok aktif justru lebih banyak yang dikategorikan IMT normal sementara yang bukan perokok lebih banyak yang obesitas. Selain itu, ada perbedaan risiko pada perokok aktif dan mantan perokok ketika distratifikasi berdasarkan indeks massa tubuh. Pada responden yang obesitas, terlihat bahwa risiko DM antara mantan perokok dengan perokok aktif hampir sama. Pada responden dengan IMT kurus, risiko DM pada perokok aktif menunjukkan risiko, sementara pada mantan perokok justru protektif. Namun, hasil keduanya tidak berhubungan secara statistik. Sementara itu, pada responden dengan IMT normal dan IMT kegemukan, risiko DM pada perokok aktif dan mantan perokok hampir sama saja dengan yang bukan perokok.

Pada penelitian Will et al di Amerika Serikat (Will et al., 2001), didapatkan hasil bahwa risiko DM pada perokok berbedabeda berdasarkan indeks masssa tubuh, baik pada laki-laki maupun perempuan. Pada orang yang overweight atau obesitas, risiko DM semakin meningkat, baik pada perokok maupun bukan perokok. Hal tersebut juga berkaitan dengan intensitas merokok, dimana perokok berat ( $\geq 2$ pak) memiliki risiko DM paling besar jika dibandingkan dengan bukan perokok. Begitu pula pada perokok, risiko DM akan semakin meningkat ketika seseorang mengalami kegemukan atau obesitas. Sementara itu, studi lain terhadap populasi wanita di Iowa, Amerika Serikat mendapatkan hasil bahwa IMT tidak memodifikasi hubungan positif antara merokok dengan diabetes mellitus, dengan hasil yang tidak berbeda jauh jika distratifikasi berdasarkan IMT (Cullen et al., 2010).

Merokok berkaitan dengan juga dengan komposisi tubuh. Hasil studi pada penderita diabetes mellitus di the Swedish National Diabetes Register (NDR) menunjukkan bahwa merokok secara independen berhubungan positif dengan kenaikan kadar HbA1c ( $<<0,001)$ tetapi berhubungan negatif dengan IMT ( $\mathrm{p}<$ 0,001) (Nilsson et al., 2004). Perokok aktif memiliki IMT 22\% lebih rendah dibandingkan bukan perokok sementara mantan perokok justru memiliki IMT 4\% lebih tinggi dibanding perokok aktif (Carreras-torres et al., 2019). Orang yang 
tidak pernah perokok dan mantan perokok memiliki perbedaan IMT dengan perokok aktif dengan rata-rata sebesar $1,6 \mathrm{~kg} / \mathrm{m}^{2}$ (Marcus R. Munafò et al., 2009). Selain itu, berhenti merokok dikaitkan dengan peningkatan rata-rata BMI sebesar 1,6 $\mathrm{kg} / \mathrm{m}^{2}$ dan menunjukkan bahwa ketika perokok sudah berhenti merokok dalam jangka panjang, IMT rata-rata mereka akan kembali setara dengan yang mereka tidak pernah merokok (Marcus R. Munafò et al., 2009).

Merokok secara akut dapat memperburuk toleransi glukosa dan indeks sensitivitas insulin (Maddatu J, Andersonbaucum E, 2018). Merokok secara signifikan meningkatkan indeks homeostatic model assessment insulin resistance (HOMA-IR) satu jam setelah merokok (Chang, 2012). Nikotin pada rokok dapat secara langsung meningkat homeostasis glukosa darah, yang berperan penting dalam kejadian diabetes mellitus tipe 2 (Maddatu J, Anderson-baucum E, 2018). Merokok juga menghambat pengambilan/penyerapan glukosa pada jaringan otot $10 \%-40 \%$ pada laki-laki yang merokok, dibandingkan dengan yang tidak merokok (Maddatu J, Anderson-baucum E, 2018).

Kelebihan dalam penelitian ini adalah menggunakan pemeriksaan HbA1c untuk menentukan status outcome, yang dinilai memberikan hasil yang lebih akurat dibanding pemeriksaan glukosa darah umumnya. Namun, misklasifikasi karena melakukan konversi nilai HbA1c dari DBS ke nilai HbA1c whole blood mungkin masih dapat terjadi. Status IMT yang di bawah normal (kategori kurus dengan IMT $<18,5 \mathrm{~kg} / \mathrm{m} 2$ ) telah dipertimbangkan sebagai kategori dalam penelitian ini mengingat kecenderungan perokok berada pada kategori IMT tersebut. Selain itu, informasi terkait jumlah batang rokok yang dihisap dan lamanya merokok juga didapatkan dalam penelitian ini, sehingga dapat dipertimbangkan sebagai variabel confounding.

Penelitian ini memiliki beberapa kelemahan yang mempengaruhi hasil penelitian. Pertama, desain studi yang digunakan adalah cross sectional, dimana kemungkinan masih adanya temporal ambiguity. Kedua, data terkait indikator lemak sentral, seperti lingkar pinggang dan/atau lingkar pinggul, hanya tersedia untuk umur $\geq 40$ tahun sehingga tidak dimasukkan sebagai variabel potential confounding. Padahal jika dilihat berdasarkan lemak sentral, perokok cenderung memiliki WHR lebih tinggi dibandingkan bukan perokok (Maddatu et al., 2018). Ketiga, masih adanya kemungkinan misklasifikasi pengukuran eksposure yang menggunakan wawancara. Dalam hal ini, status outcome juga mungkin masih dipengaruhi oleh misklasifikasi karena melakukan konversi nilai $\mathrm{HbA1c}$ dari DBS ke nilai $\mathrm{HbA1c}$ whole blood. Keempat, hasil masih dipengaruhi oleh residual confounding dari potential confounding lainnya yang tidak dapat dianalisis dalam penelitian ini, termasuk terkait gaya hidup seperti pola makan, aktivitas fisik, konsumsi alkohol.

\section{Kesimpulan}

Pada penelitian ini terlihat bahwa perokok aktif justru lebih banyak yang dikategorikan IMT normal sementara yang bukan perokok lebih banyak yang obesitas. Perbedaan risiko pada perokok aktif dan mantan perokok ketika distratifikasi berdasarkan indeks massa tubuh, hanya terlihat pada strata IMT kurus dan obesitas, sementara pada IMT normal dan kegemukan, risiko perokok aktif dan mantan perokok tidak berbeda dengan bukan perokok. Namun, hasil ini mungkin dipengaruhi dengan kurangnya informasi terhadap potential confounding lainnya, terutama pada variabel yang diketahui 
Hubungan Antara Merokok Dengan Diabetes Mellitus Berdasarkan Indeks Massa Tubuh (Analisis Data Ifls 5

berkaitan dengan diabetes mellitus, seperti lemak sentral. Data lain yang berkaitan dengan status merokok juga menjadi variabel penting untuk dianalisis. Oleh karena itu, penelitian selanjutnya diharapkan dapat menganalisis durasi merokok dan juga melibatkan variabel potential confounding lainnya.

\section{BIBLIOGRAFI}

Akter, S., Goto, A., \& Mizoue, T. (2017). Smoking And The Risk Of Type 2 Diabetes In Japan: A Systematic Review And Meta-Analysis. Journal Of Epidemiology, 27(12), 553-561. Google $\underline{\text { Scholar }}$

Campagna, G., Xu, S., Moradshahi, M., Socher, R., \& Lam, M. S. (2019). Genie: A Generator Of Natural Language Semantic Parsers For Virtual Assistant Commands. Proceedings of The 40th Acm Sigplan Conference On Programming Language Design And Implementation, 394-410. Google $\underline{\text { Scholar }}$

Carreras-Torres, R., Johansson, M., Haycock, P. C., Relton, C. L., Smith, G. D., Brennan, P., \& Martin, R. M. (2019). Role Of Obesity In Smoking Behaviour: Mendelian Randomisation Study In Uk Biobank. Google Scholar

Chang, S. A. (2012). Smoking And Type 2 Diabetes Mellitus. Diabetes \& Metabolism Journal, 36, 399-403. $\underline{\text { Google Scholar }}$

Cullen, M. W., Ebbert, J. O., Vierkant, R. A., Wang, A. H., \& Cerhan, J. R. (2010). No Interaction Of Body Mass Index And Smoking On Diabetes Mellitus Risk In Elderly Women. Prev Med, 48(1), 74 78. Google Scholar

Dare, S., Mackay, D. F., \& Pell, J. P. (2015). Relationship Between Smoking And Obesity: A Cross-Sectional Study Of 499,504 Middle-Aged Adults In The Uk General Population. Plos One, 10(4),

\section{E0123579. Google Scholar}

Isfandari, S., Balitbangkes, R. I., Hanafi, I. N., Rumah Sakit Sanglah Denpasar, B., Asril, A., Utami, D. S., Martdiati, R., \& Sarasvita, R. (2019). Terapi Rumatan Metadone: Ketanggapan Pasien, Sikap Staff Dan Penerimaan Masyarakat. Google Scholar

Kodama, Y., Shumway, M., \& Leinonen, R. (2012). The Sequence Read Archive: Explosive Growth Of Sequencing Data. Nucleic Acids Research, 40(D1), D54D56. Google Scholar

Luo, X., Wang, J., Dooner, M., \& Clarke, J. (2015). Overview Of Current Development In Electrical Energy Storage Technologies And The Application Potential In Power System Operation. Applied Energy, 137, 511536. Google Scholar

Maddatu J, Anderson-Baucum E, E. C. (2018). Smoking And The Risk Of Type 2 Diabetes. Hhs Public Access Transl Res Author Manuscr ; 184: 101-107. Google Scholar

Maddatu, J., Anderson-Baucum, E., \& EvansMolina, C. (2018). Smoking And The Risk Of Type 2 Diabetes. Hhs Public Access Translational Research. Author Manuscript, 184(317), 101-107. Google $\underline{\text { Scholar }}$

Marcus R. Munafò, Tilling, K., \& BenShlomo, Y. (2009). Smoking Status And Body Mass Index: A Longitudinal Study. Nicotine \& Tobacco Research, 11(6), 765-771. Google Scholar

Mehta, P., Bukov, M., Wang, C.-H., Day, A. G. R., Richardson, C., Fisher, C. K., \& Schwab, D. J. (2019). A High-Bias, LowVariance Introduction To Machine Learning For Physicists. Physics Reports, 810, 1-124. Google Scholar

Nilsson, P. M., Gudbjörnsdottir, S., Eliasson, B., \& Cederholm, J. (2004). Smoking Is Associated With Increased Hba1c Values 
And Microalbuminuria In Patients With Diabetes - Data From The National Diabetes Register In Sweden. Diabetes Metab, 30, 261-269. Google Scholar

Saeedi, P., Petersohn, I., Salpea, P., Malanda, B., Karuranga, S., Unwin, N., Colagiuri, S., Guariguata, L., Motala, A. A., \& Ogurtsova, K. (2019). Global And Regional Diabetes Prevalence Estimates For 2019 And Projections For 2030 And 2045: Results From The International Diabetes Federation Diabetes Atlas. Diabetes Research And Clinical Practice, 157, 107843. Google Scholar
Will, J. C., Galuska, D. A., Ford, E. S., \& Calle, E. E. (2001). Cigarette Smoking And Diabetes Mellitus: Evidence Of A Positive Association From A Large Prospective Cohort Study. International Journal Of Epidemiology, 30, 540-546. Google Scholar

Wipfli, H. (2012). The Tobacco Atlas. Oxford University Press. Google Scholar

\section{Copyright holder :}

Dian Kartika Irnayanti dan Krisnawati Bantas (2021)

First publication right :

Jurnal Health Sains

This article is licensed under:

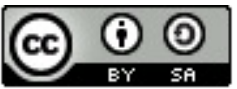

